\title{
Ascorbate modulates the hypoxic pathway by increasing intracellular activity of the HIF hydroxylases in renal cell carcinoma cells
}

This article was published in the following Dove Press journal: Hypoxia

\author{
Christina Wohlrab' \\ Caroline Kuiper ${ }^{2}$ \\ Margreet CM Vissers ${ }^{2}$ \\ Elisabeth Phillips' \\ Bridget A Robinson 1,3 \\ Gabi U Dachs'
}

'Mackenzie Cancer Research Group, Department of Pathology and Biomedical Science, University of Otago,

Christchurch, New Zealand; ${ }^{2}$ Centre for Free Radical Research, Department of Pathology and Biomedical Science, University of Otago, Christchurch, New Zealand; ${ }^{3}$ Canterbury Regional Cancer and Hematology Service, Canterbury District Health Board, Christchurch, New Zealand
Correspondence: Gabi U Dachs Mackenzie Cancer Research Group, Department of Pathology and Biomedical Science, University of Otago,

Christchurch, PO Box 4345, Christchurch

8140 , New Zealand

Tel +6423640544

Fax +6433640525

Email gabi.dachs@otago.ac.nz
Purpose: Protein levels and activity of the hypoxia-inducible transcription factors HIF-1 and HIF-2 are controlled by hydroxylation of the regulatory alpha chains. Proline hydroxylases (PHDs) target the protein for degradation via the von-Hippel-Lindau (VHL)ubiquitin-ligase complex, and asparagine hydroxylation by Factor Inhibiting HIF (FIH) leads to transcriptional inactivation. In cell-free systems, these enzymes require ascorbate as a cofactor, and this is also inferred to be an intracellular requirement for effective hydroxylation. However, how intracellular concentrations of ascorbate affect hydroxylase activity is unknown. In this study, we investigated the modulation of the regulatory hydroxylases in cancer cells by intracellular ascorbate.

Materials and methods: To facilitate this investigation, we used clear cell renal carcinoma cell lines that were VHL-proficient (Caki-1), with a normal hypoxic response, or VHLdefective (Caki-2 and 786-0), with uncontrolled accumulation of HIF- $\alpha$ chains. We monitored the effect of intracellular ascorbate on the hypoxia-induced accumulation of HIF-1 $\alpha$, HIF-2 $\alpha$ and the expression of downstream HIF targets BNIP3, cyclin D1 and GLUT1. Changes in hydroxylation of the HIF-1 $\alpha$ protein in response to ascorbate were also investigated in 786-0 cells gene-modified to express full-length HIF-1 $\alpha$ (786-HIF1).

Results: In VHL-proficient cells, hypoxia induced accumulation of HIF-1 $\alpha$ and BNIP3 which was dampened in mild hypoxia by elevated intracellular ascorbate. Increased HIF$2 \alpha$ accumulation occurred only under severe hypoxia and this was not modified by ascorbate availability. In VHL-defective cells, ascorbate supplementation induced additional accumulation of HIF under hypoxic conditions and HIF pathway proteins were unchanged by oxygen supply. In 786-HIF1 cells, levels of hydroxylated HIF-1 $\alpha$ were elevated in response to increasing intracellular ascorbate levels.

Conclusion: Our data provide evidence that the hypoxic pathway can be modulated by increasing HIF hydroxylase activity via intracellular ascorbate availability. In VHL-defective cells, accumulation of HIF-alpha proteins is independent of hydroxylation and is unaffected by intracellular ascorbate levels.

Keywords: vitamin C, hypoxia inducible factor-1, kidney cancer, ccRCC, VHL, PHD

\section{Introduction}

Solid tumors frequently contain hypoxic areas due to poor vascularization or formation of dysfunctional blood vessels that result in inadequate tissue oxygenation. ${ }^{1}$ Adaptation of cells to these conditions of limited oxygen supply is mediated via the pro-survival transcription factors hypoxia-inducible factors (HIF-1 and HIF-2) by regulating the expression of hundreds of genes involved in cellular metabolism, cell life and death 
pathways, glycolysis and angiogenesis. As a result, the HIFs promote tumor growth, adaptation to the microenvironment and resistance to chemo- and radio-therapy. ${ }^{2}$ HIF-binding controls not only gene transcription but also modifies nucleosome organization. ${ }^{49}$ HIF-1 and HIF-2 regulate common and unique sets of genes, and although they share a consensus enhancer, each bind discreet sequences across the genome. ${ }^{50}$ For example, both isoforms upregulate vascular endothelial growth factor (VEGF-A) and glucose transporter 1 (GLUT1), whereas HIF-1 mainly controls glyceraldehyde3-phosphate dehydrogenase, carbonic anhydrase 9 and Bcl2/ adenovirus E1B $19 \mathrm{kDa}$ interacting protein 3 (BNIP3), and HIF-2 controls erythropoietin, cyclin D1 and matrix metalloproteinase $1^{46,29}$.

HIFs consist of regulatory $\alpha$-subunits (HIF- $1 \alpha$, HIF- $2 \alpha$ and HIF-3 $\alpha$ ) and a constitutively expressed HIF- $1 \beta$ subunit. Under physiological conditions, protein levels and the transcriptional activity of HIFs are tightly regulated by post-translational modification of the $\alpha$-subunit by hydroxylase enzymes belonging to the family of ironand 2-oxoglutarate-dependent dioxygenases., ${ }^{3,4}$ Hydroxylation of two prolines (P402 and P564 of HIF$1 \alpha, \mathrm{P} 405$ and P531 of HIF-2 $\alpha$ ) by proline hydroxylases (PHDs) targets the protein for proteasomal degradation via the von-Hippel-Lindau (VHL)-ubiquitin-ligase complex, and asparagine hydroxylation (N803 of HIF-1 $\alpha$, N847 of HIF- $2 \alpha$ ) by factor inhibiting HIF (FIH) leads to its transcriptional inactivation. ${ }^{5-7}$ Both PHD and FIH enzymes require ascorbate as a cofactor, and absence of ascorbate leads to increased HIF activation. ${ }^{8-10}$

Previous investigations by us, and others, have indicated an association between tissue ascorbate levels and activation of the HIFs. This has been observed in tumor tissue from patients with endometrial, colorectal, thyroid and papillary cell renal cell carcinoma with these studies showing an inverse association between tissue ascorbate and markers of activation of the HIF pathway. ${ }^{11-14}$ Whereas these studies are suggestive of an impact of ascorbate on tumor hypoxia responses, to date, the impact of ascorbate on hydroxylation of HIF-1 $\alpha$ has only been directly investigated in cell-free systems. Using recombinant proteins, Jaakkola et al demonstrated that PHDs rely on ascorbate for full activity for the hydroxylation of P564. ${ }^{15}$ Adding ascorbate $(2 \mathrm{mM})$ to the reaction mix increased the interaction between a HIF- $1 \alpha$ fusion protein and VHL in a capture assay, indicating increased hydroxylation. Subsequently, the dependence of both PHD2 and $\mathrm{FIH}$ on ascorbate was investigated in reactions with different short HIF- $1 \alpha$ peptides each containing one of the three hydroxylation sites (P402, P564 or N803) using matrix-assisted laser desorption ionization-time of flight mass spectrometry. ${ }^{16}$ Ascorbate $(4 \mathrm{mM})$ was able to enhance both the rate and extent of hydroxylation, with a bigger impact on PHD2 than on FIH. ${ }^{16}$ This stimulatory effect was specific to ascorbate, and was not able to be substituted by other reducing agents such as glutathione. ${ }^{16}$ Interestingly, intracellular ascorbate levels in vivo are known to be maintained in the $\mathrm{mM}$ range by active uptake via the sodium-dependent vitamin $\mathrm{C}$ co-transporters (SVCTs). ${ }^{17-19}$ It is unknown whether these concentrations are required for effective activity of the intracellular hydroxylases or whether there is a minimum threshold for optimal regulation. We have investigated this relationship with the full-length protein in live, intact cells.

Clear cell renal cell carcinoma (ccRCC) is a serious urological malignancy that harbors alterations in the $V H L$ tumor suppressor gene leading to uncontrolled accumulation of $\mathrm{HIF}^{20}{ }^{2}$ Human ccRCC cell lines are available with different VHL mutation status, and these are valuable for investigating the involvement of VHL in the HIF response to ascorbate. Our recent clinical and in vitro data (mild hypoxia with high dose ascorbate ${ }^{14}$ ) suggested a VHL-dependent regulation of HIF-pathway activity by ascorbate. To test the hypothesis that increasing levels of intracellular ascorbate contribute to increasing activity of the HIF hydroxylases, we measured the stabilization of HIF- $1 \alpha$ and HIF- $2 \alpha$, as well as the downstream target protein expression of both HIF-1 and HIF-2 in ccRCC cells with VHL-proficient or VHL-deficient status under a range of physiological concentrations of oxygen and ascorbate. In addition, we have directly monitored the hydroxylation of full-length HIF-1 $\alpha$ in response to changes in intracellular ascorbate content in whole cells.

\section{Materials and methods}

\section{Cell lines}

The human ccRCC cell lines Caki-1 (HTB-46), Caki-2 (HTB-47) and 786-0 were obtained from the American Type Culture Collection (ATCC; Manassas, VA, USA), and used at early passages $(<20)$. Caki- 1 and Caki- 2 cells were maintained in McCoy's 5A (modified) medium and 786-0 cells in DMEM supplemented with $10 \%$ fetal bovine serum (FBS) and 1\% Antibiotic-Antimycotic solution (all from Life Technologies, Carlsbad, CA, USA) at a temperature of $37^{\circ} \mathrm{C}$, a relative humidity of $95 \%$ and an 
atmosphere containing $5 \% \mathrm{CO}_{2}$. Cells were utilized in experiments at $70-80 \%$ confluency $\left(\sim 2 \times 10^{4}\right.$ cells $/ \mathrm{cm}^{2}$ with shallow media coverage) to avoid cell-densityinduced and $\mathrm{O}_{2}$-diffusion-limited $\mathrm{HIF}$ stabilization. ${ }^{51,52}$ Caki-1 cells express both HIF- $1 \alpha$ and HIF- $2 \alpha$ and have a VHL wild-type status, ${ }^{6,21}$ Caki-2 express only HIF-1 $\alpha$ and have a mutant VHL status ${ }^{22,23}$ (VHL status was confirmed by Sanger sequencing due to conflicting published data, results not shown), and 786-0 cells express only HIF$2 \alpha$ and have a mutant VHL status. ${ }^{6,21}$ Cell lines were routinely tested for mycoplasma contamination with a PCR-based assay using generic primers. ${ }^{24}$

\section{Lentiviral transduction of 786-0 cells}

For lentiviral transduction of 786-0 cells with the human HIF-1 $\alpha$-encoding gene, the coding sequence was excised from HA-HIF-1-wt-pBabe-puro (a gift from William Kaelin, Addgene plasmid \#19365, Addgene, Cambridge, MA, USA) and inserted into pFUGW (a gift from David Baltimore, Addgene plasmid \#14883) using the restriction enzymes BamHI and EcoRI, placing HIF- $1 \alpha$ expression under control of the ubiquitin $C$ promoter. Use of this exogenous promoter was deliberate as it ensures reduced interference from the endogenous HIF-1 promoter in response to hypoxia or ascorbate. Lentivirus was produced in 293FT cells (Invitrogen, Carlsbad, CA, USA) via co-transfection with pFUGW-HA-HIF- $1 \alpha, \mathrm{p} \Delta 8.9$ and $\mathrm{pVSVG}$ using LTX Plus (Invitrogen), according to established protocols. ${ }^{25,26}$ Sodium-butyrate $(7 \mathrm{mM})$ was added after $24 \mathrm{hrs}$ and supernatants containing lentivirus particles were harvested $72 \mathrm{hrs}$ post-transfection and stored at $-80^{\circ} \mathrm{C} .786-0$ were transduced with lentivirus stock for $6 \mathrm{hrs}$, and selection with Zeocin $(0.5$ $\mu \mathrm{g} / \mathrm{ml}$, Thermo Fisher Scientific, Waltham, MA, USA) was started $72 \mathrm{hrs}$ post-transduction. Zeocin-resistant clones were selected over 16 days and tested for HIF- $1 \alpha$ protein using Western blot analysis (described below). Transduced 786-0 clones were maintained in $0.5 \mu \mathrm{g} / \mathrm{ml}$ Zeocin, and the clone used in this study was named 786-HIF1.

\section{Ascorbate uptake}

Cells were grown to $70-80 \%$ confluence in 12 -well plates in normal culture media. Media was found to contain no detectable levels of ascorbate. A $100 \mathrm{mM}$ stock solution of sodium ascorbate was prepared fresh in phosphatebuffered saline (PBS), filter-sterilized and added to the medium to final concentrations between $50 \mu \mathrm{M}$ to $1 \mathrm{mM}$. Following exposure, media was removed, cells were pel-

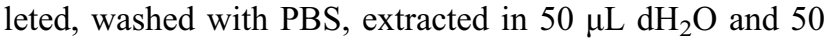

$\mu \mathrm{L} 0.54 \mathrm{M}$ perchloric acid containing $50 \mathrm{mM}$ diethylene triamine penta-acetic acid to precipitate protein and stabilize ascorbate and the supernatant was collected following centrifugation at $4^{\circ} \mathrm{C}$. Samples were then reduced with Tris(2-carboxyethyl)phosphine $(10 \mathrm{mg} / \mathrm{mL})$ for $3 \mathrm{hrs}$ at $4^{\circ} \mathrm{C}$ to yield total ascorbate prior to high-performance liquid chromatography (HPLC) analysis.

\section{Hypoxia treatment}

HIF was stabilized in the RCC cell lines by exposure to hypoxic conditions $\left(0.1 \%, 1 \%, 5 \%\right.$ or $\left.10 \% \mathrm{O}_{2}\right)$. Cells were seeded into 6 -well plates, grown to $70-80 \%$ confluence in air and placed in a H35 Hypoxystation (Don Whitley Scientific Limited, Shipley, UK) for $8 \mathrm{hrs}$ at $37^{\circ} \mathrm{C}$, gassed with a defined oxygen concentration with a balance of $\mathrm{N}_{2}$ and $5 \% \mathrm{CO}_{2}$. Incubation under hypoxia for $4-8 \mathrm{hrs}$ is sufficient, and usually optimal, to induce changes in protein expression of HIF pathway proteins. ${ }^{10,18,54}$ To evaluate the effect of ascorbate on stabilization of HIF, cells were pre-loaded with ascorbate for $16 \mathrm{hrs}$ prior to hypoxia treatment, with continued ascorbate in the media. Cells were lysed on the plates in RIPA buffer with complete proteinase inhibitor cocktail (Roche, Basel, Switzerland), collected using a cell scraper and further processed by aspirating through a $27 \mathrm{G}$ needle and cell debris was removed by centrifugation at $4^{\circ} \mathrm{C}$. Supernatants were used for Western blot analysis.

\section{Ascorbate analysis}

Ascorbate content of cell lysates was measured by HPLC in reversed phase separation mode coupled to an electrochemical detector (Thermo Fisher Scientific, Waltham, MA, USA). The system consisted of an Ultimate 3000 HPLC unit with an Ultimate 3000 ECD-3000RS electrochemical detector and a Model 6011RS coulometric cell (guard cell $=300 \mathrm{mV}$; analytical electrode $=200 \mathrm{mV}$; sensitivity $=20 \mu \mathrm{A}$ ). The autosampler was maintained at $4^{\circ} \mathrm{C}$ and the column oven at $30^{\circ} \mathrm{C}$. The mobile phase $(80 \mathrm{mM}$ sodium acetate, $0.54 \mathrm{mM}$ DTPA, $0.017 \%$ n-octylamine) run at constant $1.2 \mathrm{~mL} / \mathrm{min}$ and $20 \mu \mathrm{L}$ of sample was injected. A standard curve ranging from 1.25 to $20 \mu \mathrm{M}$ ascorbate was prepared fresh each time using sodiumL-ascorbate diluted in $77 \mathrm{mM}$ perchloric acid with $25 \mathrm{mM}$ DTPA.

\section{Western blot analysis}

Proteins $(20 \mu \mathrm{g} / \mathrm{well})$ were separated on $4-12 \%$ Bis-Tris Plus SDS gels and transferred to $0.45 \mu \mathrm{m}$ polyvinylidene difluoride membranes. The same positive control $(20 \mu \mathrm{g}$ 
protein of $1 \% \mathrm{O}_{2}$ hypoxia-treated $\mathrm{T} 24$ cell lysate) was run on each gel to normalize signals between the blots. Following transfer, membranes were cut into strips to identify the HIF pathway proteins simultaneously (examples of original Western blots are shown in Figure S1). Membranes were incubated overnight at $4^{\circ} \mathrm{C}$ with primary antibodies against HIF-1 $\alpha$ (1/800, BD Biosciences, SanJose, CA, USA, BD610958), hydroxy-HIF-1 $\alpha$ (Pro564) (1/1000, Cell Signaling, Danvers, MA, USA, 3434), HIF-2 $\alpha$ (1/400, R\&D Systems, Minneapolis, MN, USA, AF2997), BNIP3 (1/1000, R\&D Systems, AF4147), cyclin D1 (1/10,000, Abcam, Cambridge, UK, ab134175), GLUT1 (1/1000; Abcam, ab32551) or B-actin (1/10,000, Sigma-Aldrich, Auckland, NZ, A5316), and for $1 \mathrm{hr}$ at room temperature with secondary anti-goat, anti-mouse or anti-rabbit horseradish peroxidase-conjugated antibodies (1/5000, DAKO, Mulgrave, Australia) as appropriate. Protein bands were detected using the ECL Prime Western Blotting Detection Reagent (GE Healthcare, Chicago, USA) and the Alliance 4.7 imaging system, and quantified with ImageJ software.

\section{Statistical analyses}

Data analysis was performed in GraphPad Prism 5. Differences between treatment conditions were tested by Oneway ANOVA with Dunnett's Multiple Comparison or Bonferroni post test. Values of $p<0.05$ were considered significant.

\section{Results}

\section{Ascorbate uptake of $c c R C C$ cell lines}

Adding increasing concentrations of ascorbate to the cell culture medium of Caki-1, Caki-2 and 786-0 cells for 16 hrs resulted in a dose-dependent increase of intracellular ascorbate levels (Figure 1A). All three cell lines reached similar maximum levels $\left(7.2,6.2\right.$ and $8.5 \mathrm{nmol} / 10^{6}$ cells, respectively). Intracellular levels of Caki-1 and Caki-2 cells appeared saturated with $500 \mu \mathrm{M}$ ascorbate, whereas ascorbate levels in 786-0 cells continued to rise with up to $1 \mathrm{mM}$ ascorbate. However, this resulted in a decrease in cell number after 16 hrs incubation, suggesting significant toxicity of ascorbate at this concentration (Figure 1B). The lower cell numbers were factored into the calculation of ascorbate per cell and did not affect the data in Figure 1A. Given that the addition of more than $500 \mu \mathrm{M}$ ascorbate did not result in any further uptake of ascorbate into Caki-1 and Caki-2 cells and did cause toxicity in the 786-0 cells, we determined that these conditions were optimal for in vitro uptake, resulting in saturating intracellular ascorbate levels.

\section{HIF pathway activation in $\mathrm{ccRCC}$ cell lines}

Levels of HIF-1 $\alpha$, HIF-2 $\alpha$ and their downstream targets were measured in the ccRCC cell lines grown under normal culture conditions $\left(20 \% \mathrm{O}_{2}\right)$ or at decreasing oxygen tensions $(10,5,1$ and $0.1 \% \mathrm{O}_{2}$ ) (Figure 2). In these experiments, the cells were not pre-loaded with ascorbate, and are ascorbate-deficient, as are most cells grown in tissue culture conditions. ${ }^{10} \mathrm{~A}$ robust response to hypoxia was noted in VHL-proficient Caki-1 cells, with both HIF-1 $\alpha$ and HIF-2 $\alpha$ being stabilized at low oxygen tension, although sensitivity differed, with HIF-1 $\alpha$ upregulation first noted at $10 \% \mathrm{O}_{2}$ and HIF- $2 \alpha$ at $1 \% \mathrm{O}_{2}$ (overall $p<0.001$ and $p<0.01$, respectively; Figure $2 \mathrm{~A}$ and $\mathrm{B})$. Levels of the HIF-1 target BNIP3 were increased 3-fold at $0.1 \% \mathrm{O}_{2}$ $(p<0.05$; Figure 2E). Levels of the common HIF-1 and HIF-2
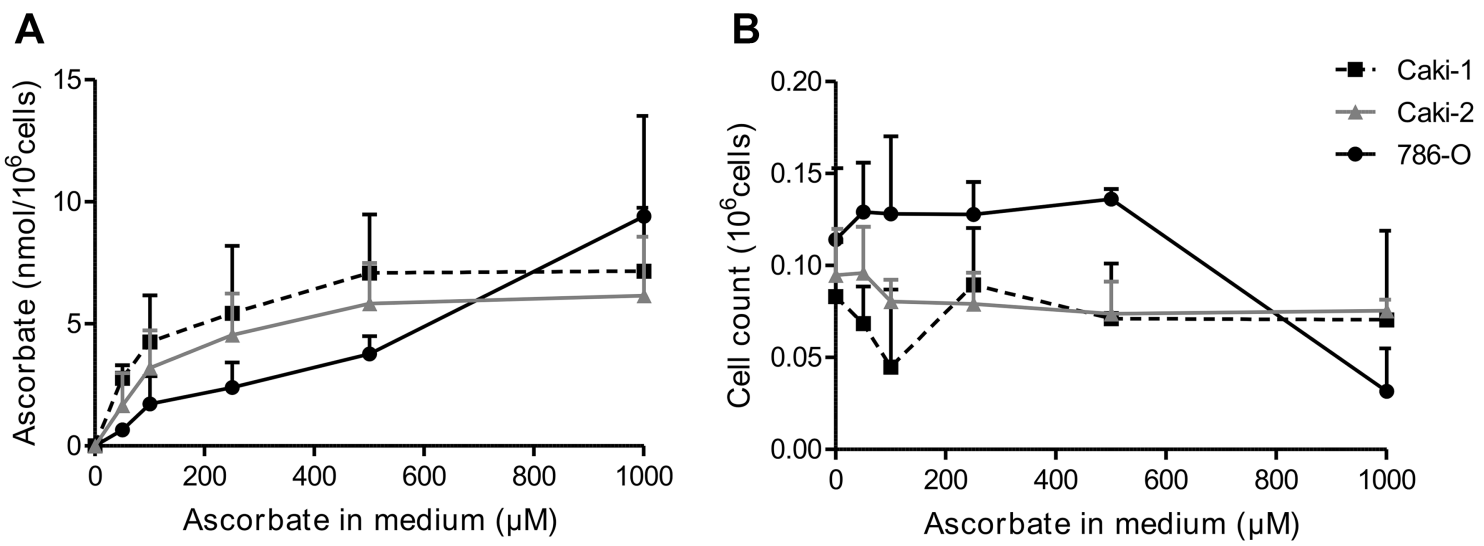

Figure I Ascorbate uptake of ccRCC cells. The ccRCC cell lines Caki-I (dotted line), Caki-2 (dark gray) and 786-0 (black) were treated with 0-I000 $\mu$ M ascorbate for I6 hrs and intracellular ascorbate content was measured in whole cell lysates by HPLC-ECD (A). Cell counts for each condition were relatively stable except for 786-0 cells which showed reduced numbers at a concentration of I mM ascorbate (B). Data are mean + SD from three independent experiments.

Abbreviations: ccRCC, clear cell renal cell carcinoma; HPLC-ECD, high-performance liquid chromatography with electrochemical detection. 
Caki-1

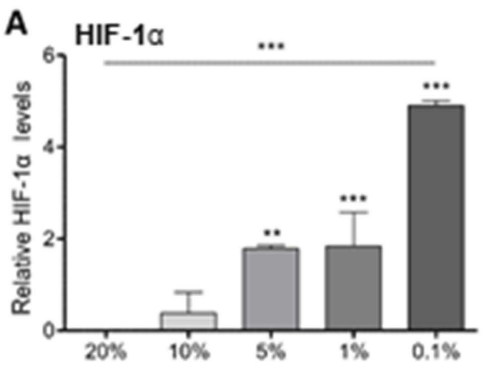

B

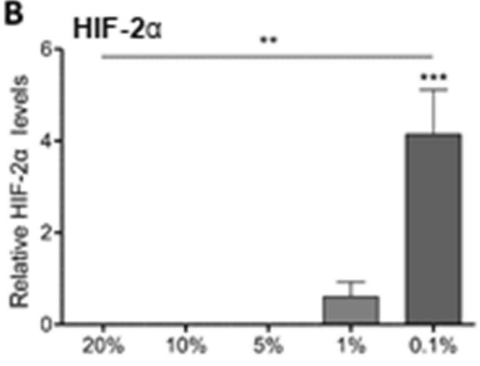

C
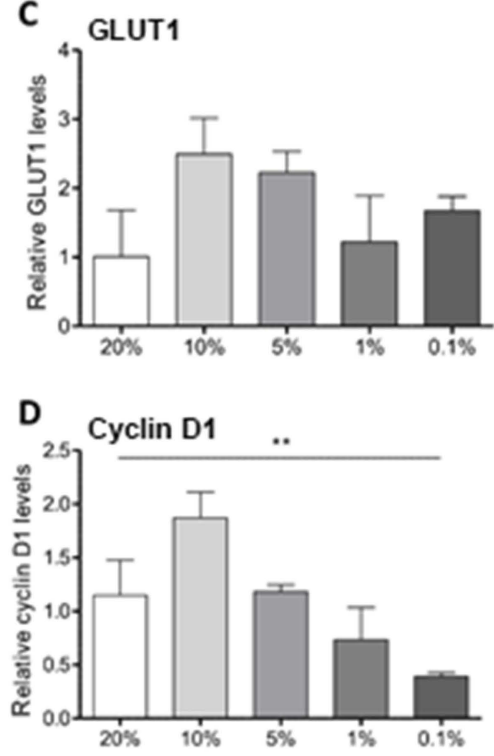

E

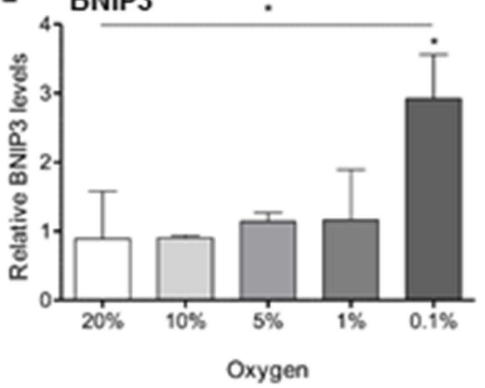

Caki-2

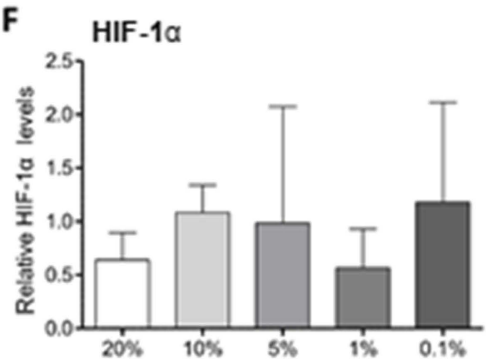

G

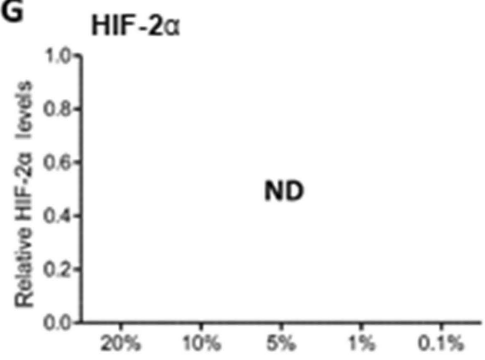

H

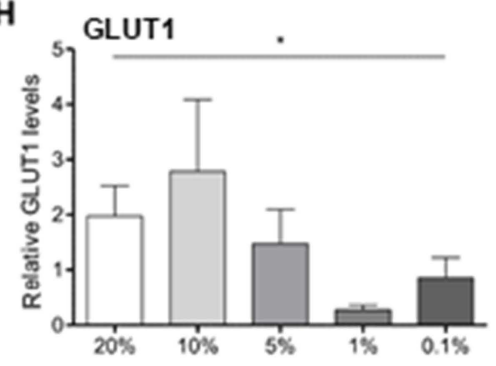

I

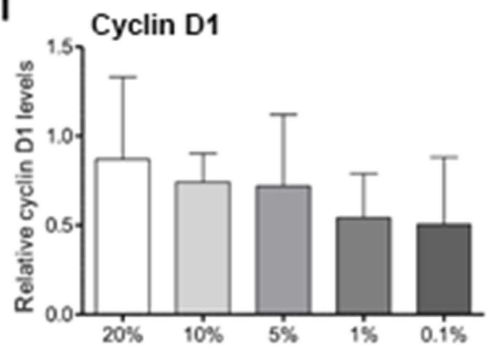

J

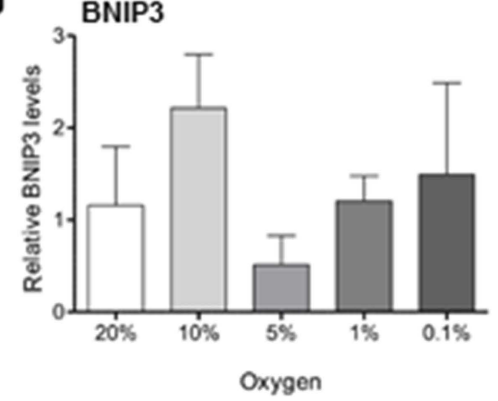

786-O

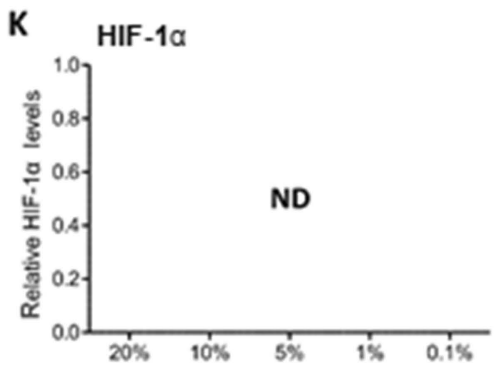

L

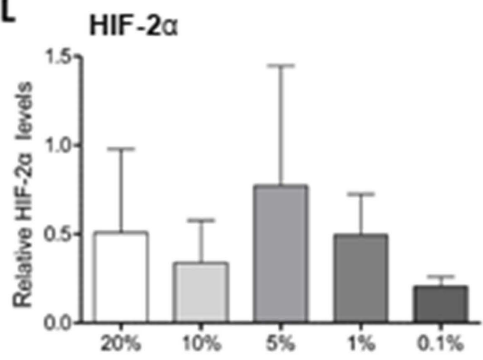

M

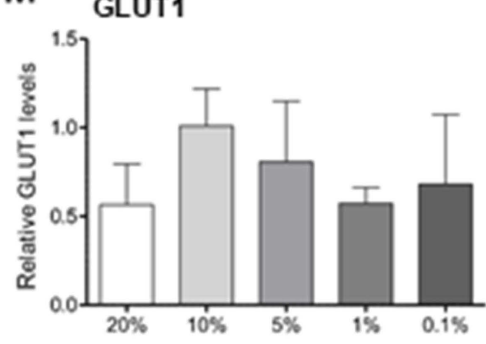

N

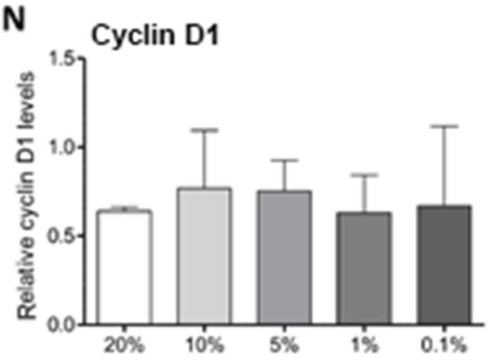

0

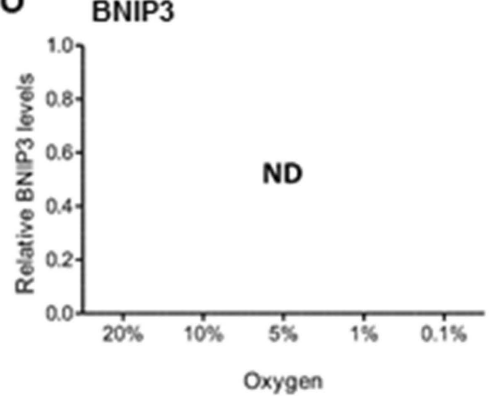

Figure 2 Hypoxic induction of HIF pathway proteins in RCC cell lines. HIF pathway proteins were analysed by Western blotting following incubation of Caki-I, Caki-2 and 786-0 in decreasing oxygen tensions for 8 hrs. Bar charts show protein levels of HIF-I $\alpha$ (A, F, K), HIF-2 $\alpha$ (B, G, L), GLUTI (C, H, M), cyclin DI (D, I, N) and BNIP3 (E, J, O) relative to a positive control (hypoxia-treated T24 cell lysate) which was loaded on each gel and referenced to $\beta$-actin. Data represent mean $+S D$ from three independent experiments. Statistical significance was evaluated by One-way ANOVA with Dunnett's Multiple Comparison Test; $* p<0.05$, $* * *<0.0$ I $* * * p<0.00 \mathrm{I}$.

Abbreviations: HIF-I $\alpha / 2 \alpha$, hypoxia-inducible factor-I $\alpha / 2 \alpha$; GLUTI, glucose transporter I; BNIP3, Bcl2/adenovirus EIB I 9 kDa interacting protein 3; ND, not detected. 
target GLUT1 varied but tended to be increased at oxygen tensions of $10 \%$ and $5 \%$ (overall $p=0.056$, Figure $2 \mathrm{C}$ ). Expression of the HIF-2 target cyclin D1 did not correlate with HIF-2 $\alpha$ stabilization and was elevated at $10 \%$ oxygen and reduced at $0.1 \%$ (overall $p<0.01$; Figure 2D).

In the VHL-defective Caki-2 cell line, HIF-1 $\alpha$ was constitutively expressed at ambient culture conditions and was not induced with decreasing oxygen tensions (Figure 2F). Correspondingly, levels of GLUT1 and BNIP3 were highly variable and generally not responsive to changes in $\mathrm{O}_{2}$ availability (Figure $2 \mathrm{H}-\mathrm{J}$ ). GLUT1 was decreased at $1 \%$ oxygen and below (overall $p<0.05$ ), and BNIP3 tended to be reduced at 5\% (overall $p=0.053)$. HIF-2 $\alpha$ was not detected in this cell line (Figure 2G) and there was no change in cyclin D1 expression at different oxygen tensions (Figure 2I).

VHL-defective 786-0 cells showed constitutive stabilization of HIF- $2 \alpha$ at $20 \%$ oxygen and this was not changed with decreasing oxygen supply (Figure 2L). As expected, ${ }^{6}$ HIF$1 \alpha$ was not detected (Figure 2K). Expression of GLUT1 and cyclin D1 remained unchanged (Figure 2M and $\mathrm{N}$ ), and BNIP3 was undetectable in this cell line (Figure 2O).

\section{The effect of ascorbate on the HIF pathway in ccRCC cell lines}

To determine the effect of intracellular ascorbate availability on hypoxia-induced HIF pathway protein levels, ccRCC cells were pre-loaded with different doses of ascorbate for $16 \mathrm{hrs}$ under ambient culture conditions and were then subjected to decreasing oxygen tensions (Figure 3-5; densitometry data shown in Figure 6). Ascorbate was available in the medium throughout the incubation.

In VHL-proficient Caki-1 cells, ascorbate was able to reduce levels of HIF-1 $\alpha$ compared to depleted cells at oxygen tensions of $10 \%$ in a dose-dependent manner $(p<0.001)$, with a similar trend at $5 \% \mathrm{O}_{2}$ (Figure 3, Figure 6A). BNIP3 showed a similar reduction, and this was significant under mild hypoxia $\left(5 \% \mathrm{O}_{2} ; p<0.01\right.$; Figure 3, Figure 6E). Expression of HIF-2 $\alpha$, which only increased at $\leq 1 \% \mathrm{O}_{2}$, was not changed by the addition of ascorbate. Levels of GLUT1 and cyclin D1 remained unchanged by ascorbate (Figure 3).

In VHL-deficient Caki-2 cells, protein levels of HIF-1 $\alpha$ were elevated with increasing ascorbate loading under lowered oxygen tensions (Figure 4). This effect was most prominent

\section{Caki-1}

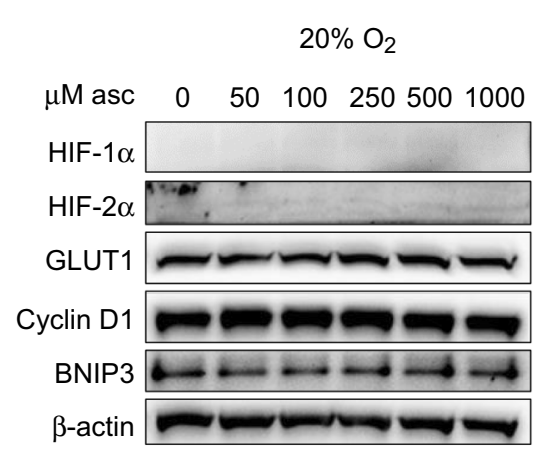

$1 \% \mathrm{O}_{2}$

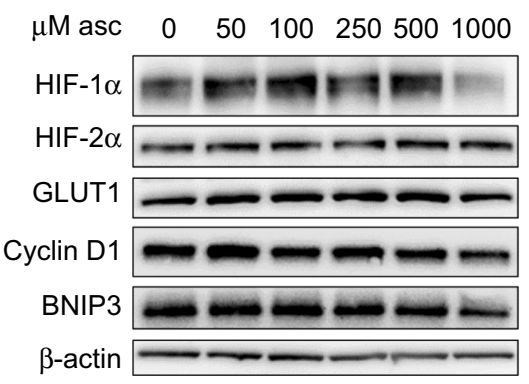

$10 \% \mathrm{O}_{2}$

$0 \quad 501002505001000$

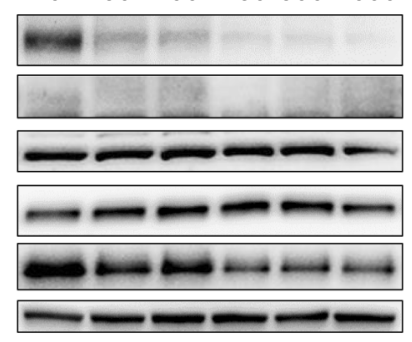

$0.1 \% \mathrm{O}_{2}$

$0 \quad 501002505001000$

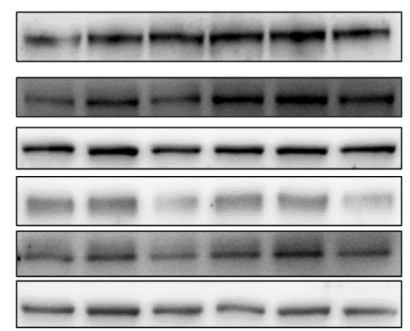

Figure 3 Effect of ascorbate on HIF pathway protein levels at different oxygen tensions in Caki-I cells. Cells were pre-loaded with increasing concentrations of ascorbate $(0-1000 \mu \mathrm{M})$ for $16 \mathrm{hrs}$ and then subjected to reduced oxygenation conditions. Shown are representative Western blots for HIF-I $\boldsymbol{\alpha}, \mathrm{HIF-2 \alpha ,}$, GLUTI, cyclin DI and BNIP3 from one of three independent experiments. $\boldsymbol{\beta}$-actin was used as a loading control. Protein levels of HIF-I $\boldsymbol{\alpha}$ and BNIP3 were decreased by ascorbate treatment under mild hypoxia $\left(1-10 \% \mathrm{O}_{2}\right)$. Other proteins were not affected.

Abbreviations: HIF-I $\alpha / 2 \alpha$, hypoxia-inducible factor-I $\alpha / 2 \alpha$; GLUTI, glucose transporter I; BNIP3, Bcl2/adenovirus EIB $19 \mathrm{kDa}$ interacting protein 3. 
Caki-2

$20 \% \mathrm{O}_{2}$

$10 \% \mathrm{O}_{2}$

$5 \% \mathrm{O}_{2}$

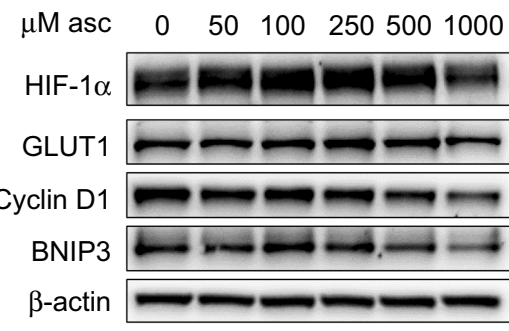

$1 \% \mathrm{O}_{2}$

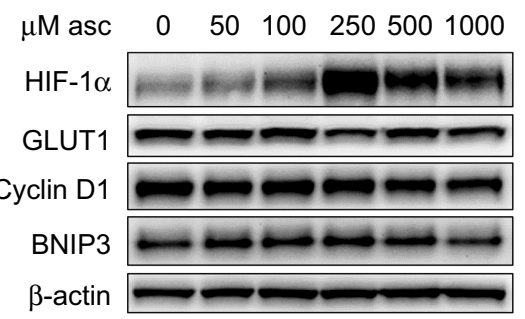

$0 \quad 50 \quad 100 \quad 2505001000$

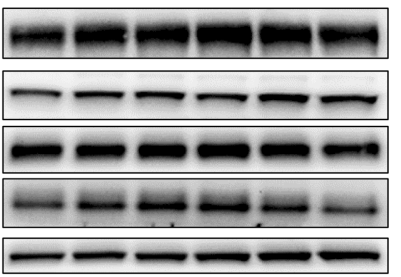

$0.1 \% \mathrm{O}_{2}$

$0 \quad 50 \quad 100 \quad 2505001000$

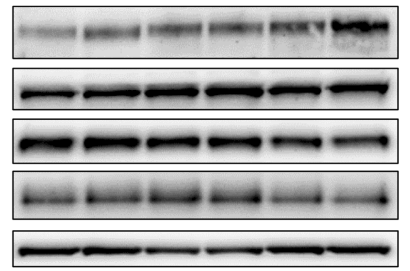

Figure 4 Effect of ascorbate on HIF pathway protein levels at different oxygen tensions in Caki-2 cells. Cells were pre-loaded with increasing concentrations of ascorbate $(0-1000 \mu \mathrm{M})$ for $16 \mathrm{hrs}$ and then subjected to reduced oxygenation conditions. Shown are representative Western blots for HIF-I $\alpha$, GLUTI, cyclin DI and BNIP3 from one of three independent experiments. $\boldsymbol{\beta}$-actin was used as a loading control. Protein levels of HIF-I $\boldsymbol{\alpha}$ were increased after ascorbate treatment at $1 \%$ and $0.1 \%$ O2. Expression of all HIF targets was unchanged.

Abbreviations: HIF-I $\alpha / 2 \alpha$, hypoxia-inducible factor- $\mid \alpha / 2 \alpha$; GLUTI, glucose transporter I; BNIP3, Bcl2/adenovirus EIB 19 kDa interacting protein 3.

786-0

$20 \% \mathrm{O}_{2}$

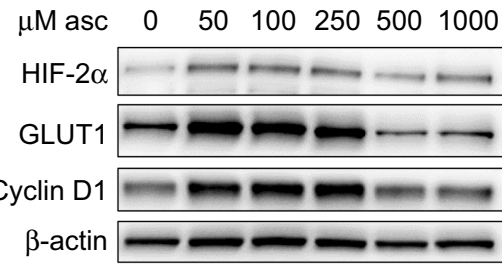

$1 \% \mathrm{O} 2$

$\mu \mathrm{M}$ asc $\quad 0 \quad 501002505001000$

HIF-2 $\longrightarrow \longrightarrow$

GLUT1 —- - - -

Cyclin D1

$\beta$-actin
$10 \% \mathrm{O}_{2}$

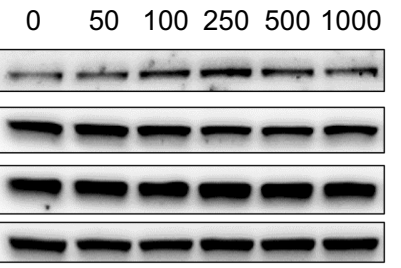

$0.1 \% \mathrm{O}_{2}$

$\begin{array}{lllll}0 & 50 & 100 & 250 & 5001000\end{array}$

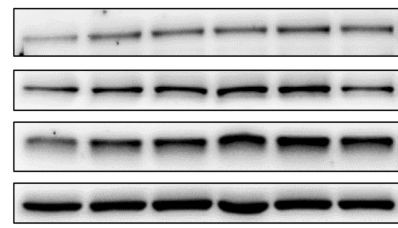

Figure 5 Effect of ascorbate on HIF pathway protein levels at different oxygen tensions in 786-0 cells. Cells were pre-loaded with increasing concentrations of ascorbate $(0-1000 \mu \mathrm{M})$ for $16 \mathrm{hrs}$ and then subjected to reduced oxygenation conditions. Shown are representative Western blots for HIF-I $\boldsymbol{\alpha}, \mathrm{HIF}-2 \boldsymbol{\alpha}, \mathrm{GLUTI}$, cyclin DI and BNIP3 from one of three independent experiments. $\boldsymbol{\beta}$-actin was used as a loading control. There was no consistent difference of protein levels after ascorbate treatment under any condition.

Abbreviations: HIF-I $\alpha / 2 \alpha$, hypoxia-inducible factor-I $\alpha / 2 \alpha$; GLUTI, glucose transporter I; BNIP3, Bcl2/adenovirus EIB 19 kDa interacting protein 3.

under severe hypoxia $\left(0.1 \% \mathrm{O}_{2} ; p<0.001\right.$; Figure $\left.6 \mathrm{~F}\right)$. The downstream targets GLUT1, cyclin D1 and BNIP3 were unaffected by ascorbate under all tested conditions (Figure 4). In
786-0 cells, protein levels of HIF-2 $\alpha$, GLUT1 and cyclin D1 were variable and were unchanged by ascorbate supplementation (Figure 5, Figure 6J-K). 
Caki-1

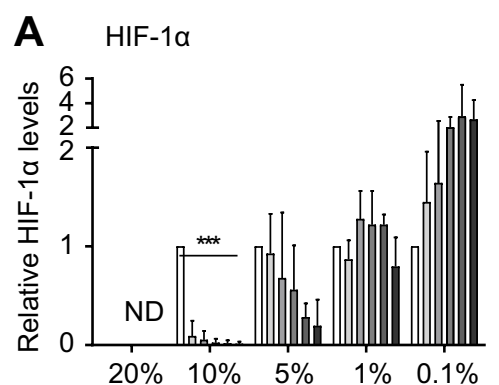

B HIF-2 $\alpha$

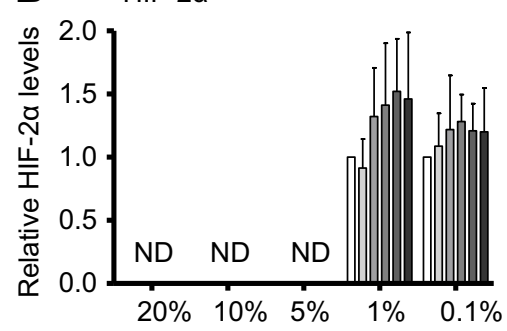

C GLUT1

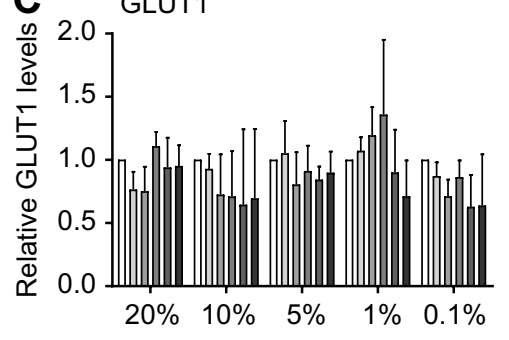

D Cyclin D1

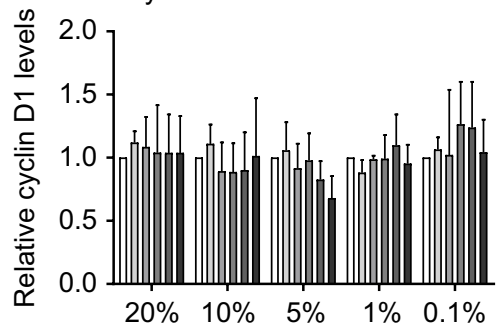

E BNIP3

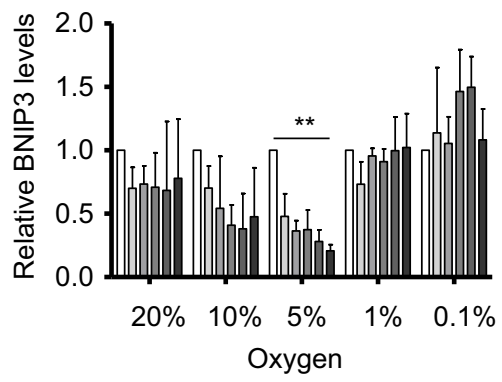

Caki-2
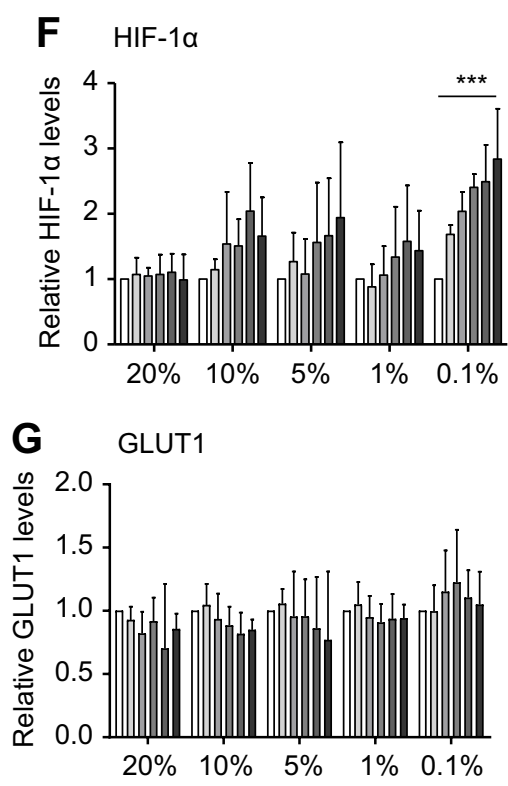

H Cyclin D1

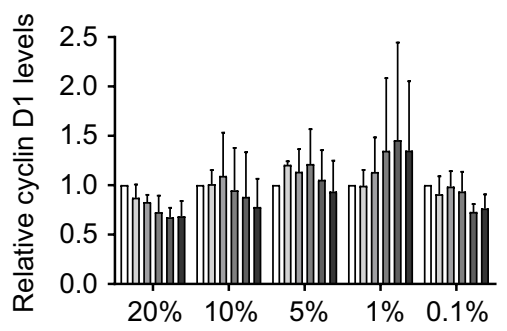

I BNIP3

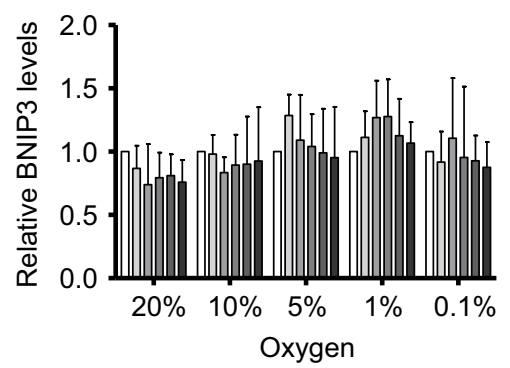

786-0

J HIF-2 $\alpha$

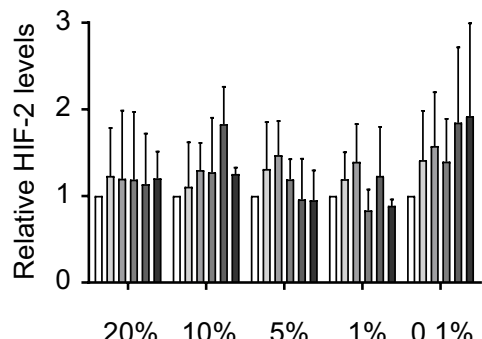

K GLUT1

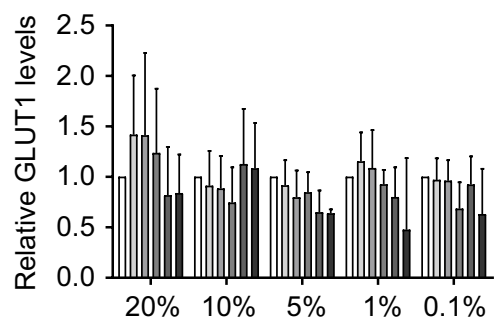

L Cyclin D1

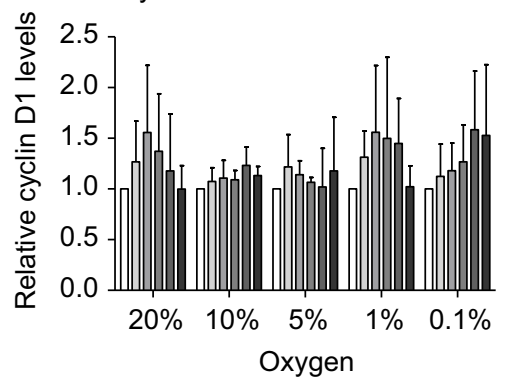

Ascorbate $\mu \mathrm{M}$

ㅁ 0

ㅁ 50

$\square 100$

口 250

500

$\square 1000$

Figure 6 Relative quantity of HIF pathway proteins in response to increasing ascorbate loading at different oxygen levels in Caki-I, Caki-2 and 786-0 cells. Densitometry analysis shows relative protein levels of HIF-I $\alpha$ (A, F), HIF-2 $\alpha$ (B, J), GLUTI (C, G, K), cyclin D I (D, H, L) and BNIP3 (E, I) in Caki-I (A-E), Caki-2 (F-I) and 786-0 (J-L) cells. Data after treatment with increasing concentrations of ascorbate $(50-1000 \mu \mathrm{M})$ at different oxygen tensions $\left(0.1-20 \% \mathrm{O}_{2}\right)$, standardised to $\beta$-actin and relative to ascorbate-deficient cells $(0$ $\boldsymbol{\mu M}$, white bar) are shown. In Caki-I cells, protein levels of HIF-I $\boldsymbol{\alpha}$ and BNIP3 were significantly decreased by ascorbate treatment under mild hypoxia. In Caki-2 cells, HIF-I $\alpha$ protein levels were significantly increased under $0.1 \% \mathrm{O}_{2}$ with increasing ascorbate. In 786-0 cells, no significant changes were observed, and no other proteins were affected. Data are mean + SD from three independent experiments. Statistical significance was determined by One-way ANOVA with Dunnett's Multiple Comparison Test; ** $p<0.01$, *** $p<0.001$. Abbreviations: HIF-I $\alpha / 2 \alpha$, hypoxia-inducible factor-I $\alpha / 2 \alpha$; GLUTI, glucose transporter I; BNIP3, Bcl2/adenovirus EIB I9 kDa interacting protein 3. 
As observed during ascorbate uptake studies (Figure 1B), high concentrations of ascorbate $(1 \mathrm{mM})$ induce cellular toxicity in vitro, and may therefore have lead to additional changes in protein levels at this high dose (Figures 3-6).

\section{Ascorbate increases Pro564 hydroxylation of HIF-I $\alpha$ in 786-HIFI cells}

To assess the effect of intracellular ascorbate on HIF-1 $\alpha$ hydroxylation, the VHL-deficient 786-0 cells were genetically modified to express wild type HIF- $1 \alpha$, generating the 786-HIF1 clone. Robust HIF-1 $\alpha$ protein expression was evident during ambient culture conditions in early passage 786HIF1 cells grown under antibiotic selection (Zeocin at 0.5 $\mu \mathrm{g} / \mathrm{mL}$ ) (P4; Figure 7A). When compared with parental 7860 cells, 786-HIF1 cells had a reduced cell growth rate after three and four days of culture $(p<0.0001$ and $p<0.0001$, respectively; Figure 7B). Over time in culture, 786-HIF1 cells increased their growth rate, approaching growth rates of parental 786-0 cells (P5 and P6; Figure 7B). This was accompanied by a loss of HIF-1 $\alpha$ expression over time in culture, despite continued antibiotic resistance (Figure 7A).

786-HIF1 cells were loaded with $500 \mu \mathrm{M}$ ascorbate and compared to no ascorbate, along with VHL-proficient Caki-1 cells that express HIF-1 $\alpha$, and whole cell lysates were analyzed with antibodies specific for hydroxylated P564 using Western blotting (Figure 7C). Hydroxylated HIF-1 $\alpha$ was only detected in 786-HIF1 cells, and levels were significantly increased in cells incubated with ascorbate compared to ascorbate-deficient cells (Figure 7D). Total HIF-1 $\alpha$ levels were slightly reduced by $500 \mu \mathrm{M}$ ascorbate, indicating VHLindependent downregulation of HIF-1 $\alpha$. Hydroxylated-HIF $-1 \alpha$ was not detected in parental 786-0 cells that do not express HIF-1 $\alpha$, nor in Caki-1 cells under ambient conditions and hypoxia $\left(1 \% \mathrm{O}_{2}\right.$; Figure $\left.7 \mathrm{C}\right)$. In Caki-1 cells, hydroxylated-HIF- $1 \alpha$ is, of course, undetectable as it is degraded upon generation.

To measure whether HIF-hydroxylation is responsive to a physiological range of ascorbate concentrations, 786HIF1 cells were loaded overnight with ascorbate ranging from $50 \mu \mathrm{M}$ to $500 \mu \mathrm{M}$. Western blot analysis indicated an increase of hydroxylated-HIF-1 $\alpha$ at P564 compared to total HIF-1 $\alpha$ protein across ascorbate doses (Figure 7E), although differences between groups were not significant (1-way ANOVA with Bonferroni post-test). Relative hydroxyl-HIF-1 $\alpha$ levels started increasing with $50 \mu \mathrm{M}$ ascorbate $\left(21 \%\right.$ increase at $0.7 \mathrm{nmol}$ ascorbate $/ 10^{6}$ cells) and treatment with $100 \mu \mathrm{M}$ ascorbate $(81 \%$ increase at 1.7 nmol ascorbate $/ 10^{6}$ cells) induced a 1.8 fold change compared to deficient cells (Figure 7F). Doses of 250-1000 $\mu \mathrm{M}$ ascorbate $(72 \%, 71 \%$ and $59 \%$ increase at $2.4,3.8$ and $9.4 \mathrm{nmol}$ ascorbate $/ 10^{6}$ cells, respectively) did not further increase hydroxylation of P564 (Figure 7F).

\section{Discussion}

This study was designed to clarify the mechanism of the modulatory effect of ascorbate on the HIF pathway and to determine whether this occurs via modulating the activity of the regulatory hydroxylases. Ascorbate is effectively taken up by ccRCC cells in culture and was able to reduce the stabilization of HIF- $1 \alpha$ and the transcriptional activity of HIF-1 at physiological concentrations, but only in cells with a functional VHL tumor suppressor protein. Elevated levels of hydroxylated HIF-1 $\alpha$ were observed in response to increasing intracellular ascorbate, directly demonstrating, for the first time, that ascorbate modulates intracellular proline hydroxylase function in living cells.

In ccRCC cells with a functional VHL protein (Caki-1 cells), HIF- $1 \alpha$ and HIF- $2 \alpha$ were both undetectable at ambient conditions $\left(20 \% \mathrm{O}_{2}\right)$ and stabilized under reduced oxygen, consistent with a functional hypoxic response; HIF-1 $\alpha$ was stabilized under very mild hypoxic conditions $\left(\leq 10 \% \quad \mathrm{O}_{2}\right)$ and HIF- $2 \alpha$ under more stringent hypoxia $\left(\leq 1 \% \mathrm{O}_{2}\right)$. This differential response to hypoxia by the two HIF isoforms adds important new information about HIF- $2 \alpha$ regulation, as previous in vitro studies only compared ambient oxygen conditions to severe hypoxia $(0.1-0.4 \%){ }^{21,27,28}$ HIF-1 is thought to govern acute adaptation to hypoxia, whereas HIF-2 acts during chronic hypoxia, although the exact mechanisms for this are unclear. ${ }^{29}$ In contrast, the VHL-defective cell lines (Caki2 and 786-0), expected to have a dysregulated hypoxic response with constant pseudohypoxic stabilization of HIF- $\alpha,{ }^{27}$ showed constitutive HIF- $1 \alpha$ and HIF- $2 \alpha$ expression under all oxygenation conditions.

Increased transcriptional activity of HIF-1 under hypoxia was evident via induction of BNIP3 in Caki-1 cells, as expected. However, GLUT1 showed no clear hypoxic induction and cyclin D1 was decreased with upregulation of both HIF isoforms. This may indicate a suppressive activity by HIFs in this VHL-proficient cell line, although deregulation by factors other than HIF cannot be excluded. Indeed, Raval et al proposed that cyclin D1 was only responsive to HIF in a VHL-defective setting, but not in a VHL-proficient setting. ${ }^{21}$ In future, other HIF-2 responsive target genes, such as 
A

\section{6-HIF1}

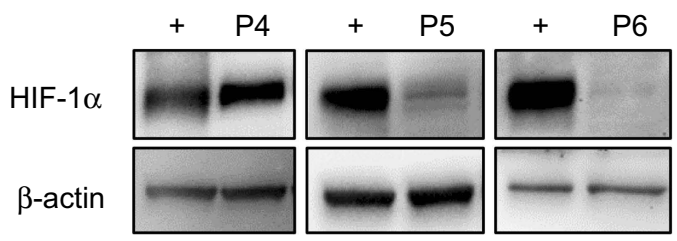

C

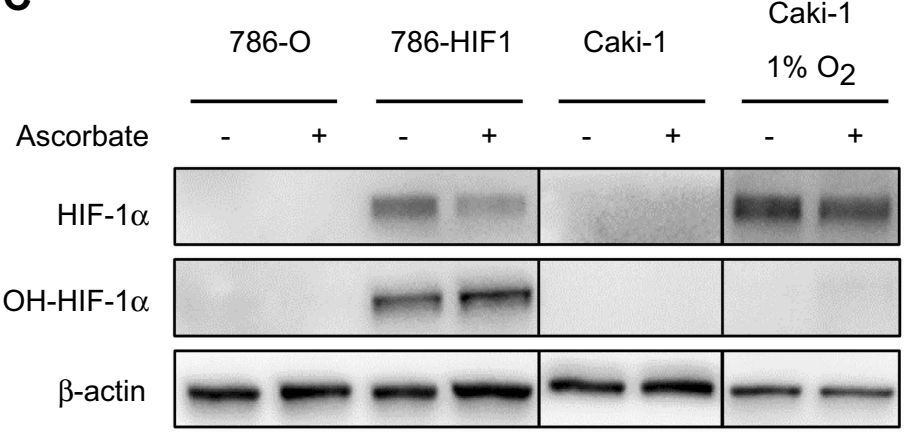

E

786-HIF1

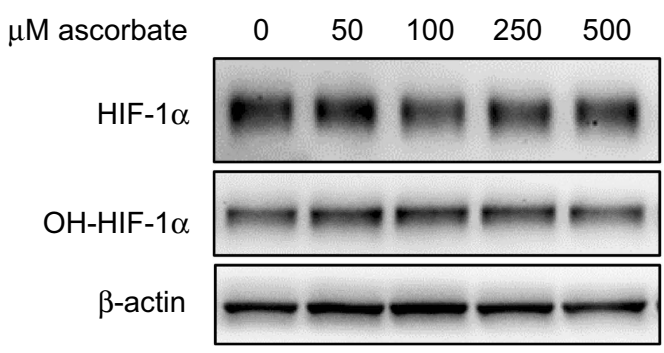

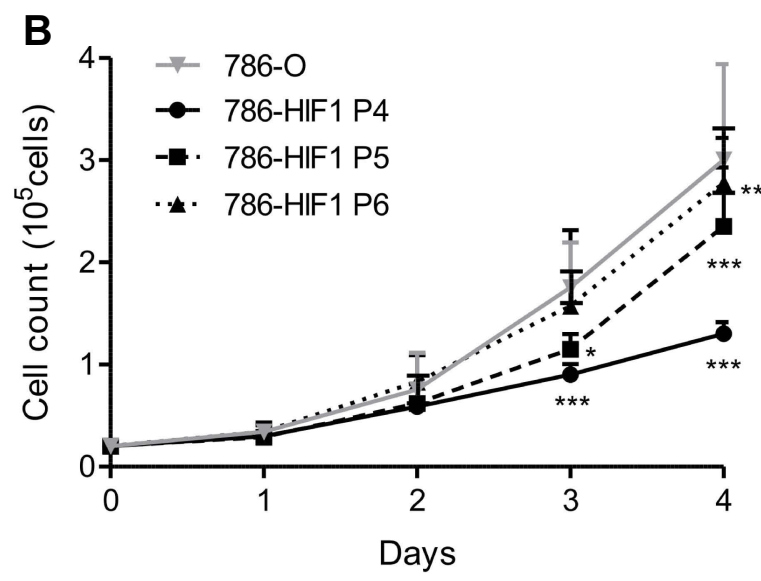

D

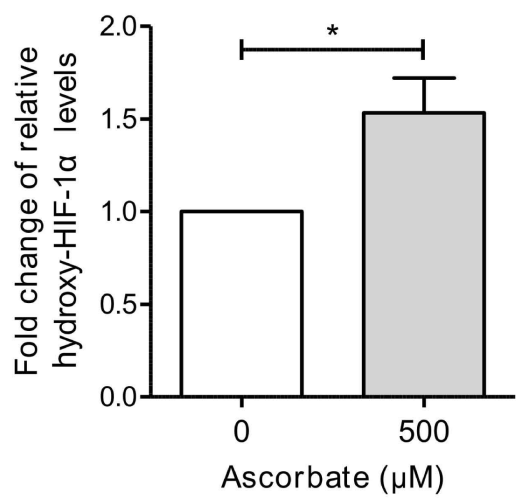

F

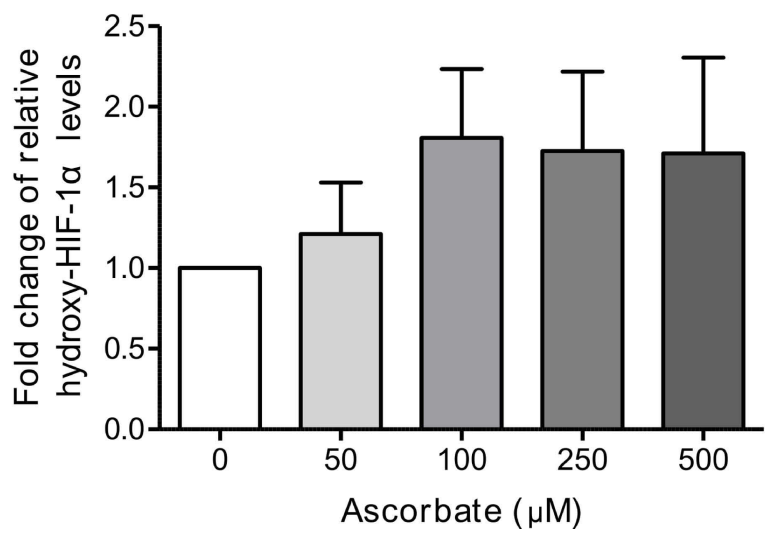

Figure 7 Proline hydroxylation of HIF-I $\alpha$ in ccRCC cell lines with or without intracellular ascorbate. Western blot analysis confirmed expression of HIF-I $\alpha$ in the 786-HIFI clones at P4 which decreased with increasing passage number (P5-P6). A hypoxia-treated T24 cell lysate was used as a positive control for HIF-I $\boldsymbol{\alpha}(+)$ and $\boldsymbol{\beta}$-actin as a loading control (A). Cell growth was monitored for four days, showing slower growth of 786-HIFI clones compared to parental cells, increasing with repeated passaging. Cell numbers are per well of a I2-well plate. Data shown as mean +SD of three independent experiments. Statistical significance compared to parental 786-0 cells was assessed using 2-way ANOVA with Bonferroni post test (B). The effect of $500 \mu \mathrm{M}$ ascorbate on P564 hydroxylation of HIF-I $\alpha$ was measured in parental 786-0 and 786-HIFI cells, and in Caki- I cells under ambient oxygen conditions or after hypoxia treatment $\left(8 \mathrm{hrs}\right.$ at $\left.1 \% \mathrm{O}_{2}\right)$ using Western blot. No hydroxy-HIF-I $\alpha$ was detected in parental 786-0 or Caki-I cells (C). Densitometry analysis shows I.5 fold increased hydroxylation in 786-HIFI cells supplied with ascorbate compared to untreated 786-HIFI cells (normalized to total HIF- $\alpha \boldsymbol{\alpha}$ content). Statistical significance was assessed by paired $t$-test (D). 786-HIFI cells were treated with $50 \mu \mathrm{M}-\mathrm{I} \mathrm{mM}$ ascorbate and cell lysates subjected to Western blot for the detection of HIF-I $\alpha$ and hydroxy-HIF- $\boldsymbol{\alpha}$ (P564) (E). Relative hydroxyHIF-I $\alpha$ (P564) levels (normalized to total HIF-I $\alpha$ levels) were increased after ascorbate treatment, as determined by densitometry analysis (F). Data shown as mean +SD from three independent experiments. Statistical significance compared to control condition was assessed by I-way ANOVA with Bonferroni post test.* $p<0.05$, ** $p<0.0 \mathrm{I}$, $* * * p^{*}<.00 \mathrm{I}$. Abbreviations: HIF-I $\alpha$, hypoxia-inducible factor-I $\alpha$; , passage number.

erythropoietin or parathyroid-hormone-related protein $\left(\mathrm{PTHr} \mathrm{P}^{53}\right)$, are therefore worth investigating in this setting. In VHL-defective Caki-2 cells, GLUT1 levels were significantly reduced under hypoxic conditions without changes in HIF-1 $\alpha$ levels, similar to previous findings in HIF-modified 786-0 cells. $^{21} 786-0$ cells showed no hypoxic induction across any 
of the proteins analyzed. Our data support the concept that the hypoxic response in ccRCC cells is complex and differs from other cancer types. ${ }^{30}$ Further analyses using gene expression studies may shed light on this complexity, although changes in mRNA levels often do not correlate with changes in protein levels. ${ }^{55,56}$ Reporter gene studies have previously demonstrated ascorbate-modulated HIF activity ${ }^{18}$ in non-ccRCC cancer cells, and may be informative in ccRCC cells.

Saturation of intracellular ascorbate was achieved with addition of $500 \mu \mathrm{M}$ ascorbate to the cell culture medium of Caki-1 and Caki-2 cells, with 786-0 cell levels increasing further with $1 \mathrm{mM}$ of ascorbate. However, the addition of $1 \mathrm{mM}$ levels of ascorbate to tissue culture media is known to be cytotoxic, potentially due to formation of cytotoxic levels of $\mathrm{H}_{2} \mathrm{O}_{2},{ }^{31-33}$ and our data also suggest toxicity against the 786-0 cells at this concentration. Similar in vitro conditions achieved intracellular ascorbate concentrations of $1.3-2 \mathrm{mM}$ in a number of cancer cell lines, ${ }^{18}$ and this coincides with the physiological range of most tissues. $^{34-36}$ We did not estimate the intracellular volume of the ccRCC cells and therefore do not have the intracellular concentrations, but the amount of ascorbate per cell is in agreement with most other measures acquired from cells in vitro. ${ }^{10,18,34,35}$ It is likely that intracellular levels in an in vivo setting are quite variable, as they are completely dependent on plasma supply (Levine papers cited above) and we have also noted a wide range of levels in tumor and normal tissues. When we recently measured ascorbate levels in ccRCC tumors, we found a range of $0.9-89.1 \mathrm{mg} /$ $100 \mathrm{~g}$ renal tumor tissue. ${ }^{14}$ These results and similar distributions in endometrial and colorectal tumors indicate a great degree of heterogeneity in human cancer cells.

The conditions required to achieve optimal intracellular concentrations in vitro appear to vary from those likely to be found in vivo. When $50 \mu \mathrm{M}$ ascorbate was added to the culture medium, reflecting average plasma levels, ${ }^{17,37}$ intracellular concentrations remained low and were readily increased when concentrations in the medium reached 500 $\mu \mathrm{M}$. We have assumed that these levels are saturating and better reflect optimal uptake in vivo, where there is a constant supply of reduced ascorbate in plasma and $100 \mathrm{uM}$ plasma levels are proposed to result in tissue saturation. $^{38}$ The intracellular concentrations reached in our cell culture conditions also indicate that at least 250 $\mathrm{uM}$ is required to achieve $\mathrm{mM}$ intracellular levels.

In cells with a functional VHL, ascorbate was able to dampen hypoxia induction of HIF-1 $\alpha$, suggesting that ascorbate acts by supporting the function of PHDs. Ascorbate had no effect on stabilization of HIF-1 $\alpha$ at $\leq 1 \%$ $\mathrm{O}_{2}$, as expected, ${ }^{18,39}$ as PHDs have an absolute requirement for oxygen as substrate, ${ }^{40}$ which cannot be overcome by additional ascorbate. Protein levels of HIF-2 $\alpha$ were not affected by ascorbate, and as these were only increased under $\leq 1 \% \mathrm{O}_{2}$, it is unclear whether ascorbate plays any role in regulating HIF- $2 \alpha$ levels. With the exception of BNIP3 levels under $5 \% \mathrm{O}_{2}$, target gene levels remained unchanged, indicating that ascorbate was not able to modify transactivation activity of HIF. Functional studies and in vitro experiments with other cell types have shown that FIH was more susceptible to ascorbate deprivation than PHD, and elevating ascorbate levels was able to increase FIH activity independent of HIF stability. ${ }^{16,18,41}$ This was not apparent in ccRCC cells in this study.

It is unclear why addition of ascorbate to the cell culture medium resulted in an apparent increase in expression of HIF-1 $\alpha$ in Caki-1 and Caki-2 cells, and HIF-2 $\alpha$ in 786-0 cells under severe hypoxia. This observation has not been reported before, and may reflect other hydroxylaseindependent pathways that regulate HIF levels under these conditions in ccRCC cells. Ascorbate is a co-factor for many 2-OG-dependent dioxygenases ( $>60$ different enzymes currently known ${ }^{42}$ ), including enzymes involved in epigenetic regulation such as the ten-eleven translocation (TET) DNA demethylases and the Jumonji domain containing protein (JMJD) histone demethylases ${ }^{43,44}$. It has been shown both in vitro and in patients samples that hypoxia increases DNA methylation by reducing TET activity, ${ }^{57}$ and increased intracellular ascorbate might be able to rescue TET activity. The interplay between TET and transcription factors is complex and not independent; indeed, binding of transcription factors is both necessary and sufficient to reduce methylation of a promoter. ${ }^{58}$ Therefore, increased TET activity together with this interplay may explain the stimulatory effects we observed in ccRCC cells.

We observed an increase in hydroxylation of HIF-1 $\alpha$ at P564 in 786-HIF1 cells treated with ascorbate. This is the first time that this causative relationship was demonstrated in live, intact cells expressing full-length HIF-1 $\alpha$. Our data support results in cell-free systems showing that ascorbate is a vital cofactor for regulatory HIF hydroxylases. ${ }^{9,15}$ It further supports findings of an association between ascorbate and the hypoxic response in human colon, endometrial, thyroid and papillary RCC tumors. ${ }^{11-14}$ In full length HIF- $1 \alpha$, P564 is hydroxylated prior to P402 based on their 
conformational position within the protein, and it also influences hydroxylation of P402. ${ }^{45}$ This makes P564 a good representative target to monitor the effect of ascorbate on the activity of PHD in cancer cells. Supplementation with $100 \mu \mathrm{M}$ ascorbate resulted in the highest induction of hydroxylation, although cells are not saturated at this dose. We conclude from this that maintaining physiological tissue ascorbate levels is able to preserve HIF pathway regulation.

786-0 cells have lost HIF-1 $\alpha$ expression, ${ }^{6}$ and thus have previously been modified to express HIF-1 $\alpha$ to investigate the differential roles of HIF-1 and HIF-2, and to study the interaction of HIF with its hydroxylases. ${ }^{21,46-48}$ In our study, 786-HIF 1 cells grew significantly slower than parental cells. Raval et al has previously shown that introduction of HIF-1 $\alpha$ into 786-0 cells resulted in downregulation of HIF- $2 \alpha$ and its downstream target cyclin D1, ${ }^{21}$ and although we did not test this, this could explain the decreased growth rate in our transfected cell line. In contrast to our data, Raval et al did not report a difference in cell growth in vitro of HIF-1 $\alpha$-transduced 786-0 cells, but showed reduced tumor growth in mouse xenografts compared to empty vector control tumors that only express HIF- $2 \alpha^{21}$ Together, these data indicate a growth disadvantage of forced HIF expression in VHL-defective ccRCC cells, which might explain the progressive loss of HIF-1 $\alpha$ expression in 786-HIF1 cells over time in culture.

\section{Conclusion}

The results from this study are consistent with the hypothesis that ascorbate controls the hypoxic pathway through its function as a cofactor for the HIF regulatory hydroxylases, as ascorbate could prevent stabilization of HIF- $\alpha$ in VHL-proficient ccRCC cells, but not in VHL-defective cells. On the contrary, in VHL-deficient cells under hypoxic conditions, ascorbate aided in accumulation of HIF- $\alpha$, indicating additional functions of ascorbate in these ccRCC cells. Elevating intracellular ascorbate levels increased hydroxylation of HIF-1 $\alpha$ on P564, confirming that PHDs rely on ascorbate for full activity to hydroxylate HIF-1 $\alpha$, and this finding reinforces the need for maintaining sufficient intracellular levels of ascorbate for the regulation of HIF pathway activity.

\section{Acknowledgments}

We gratefully acknowledge financial support from Cancer Research Trust NZ (formerly Genesis Oncology), the Mackenzie Charitable Foundation and the University of Otago (PhD Scholarship to CW).

\section{Author contributions}

All authors contributed to data analysis, drafting and revising the article, gave final approval of the version to be published, and agree to be accountable for all aspects of the work.

\section{Disclosure}

The authors report no conflict of interest in this work.

\section{References}

1. Harris AL. Hypoxia - a key regulatory factor in tumour growth. Nat Rev Cancer. 2002;2(1):38-47. doi:10.1038/nrc704

2. Majmundar AJ, Wong WJ, Simon MC. Hypoxia-inducible factors and the response to hypoxic stress. Mol Cell. 2010;40(2):294-309. doi:10.1016/j.molcel.2010.09.022

3. Lando D, Peet DJ, Gorman JJ, Whelan DA, Whitelaw ML, Bruick RK. FIH-1 is an asparaginyl hydroxylase enzyme that regulates the transcriptional activity of hypoxia-inducible factor. Genes Dev. 2002;16(12):1466-1471. doi:10.1101/gad.991402

4. Berra E, Benizri E, Ginouvès A, Volmat V, Roux D, Pouysségur J. HIF prolyl-hydroxylase 2 is the key oxygen sensor setting low steady-state levels of HIF-1alpha in normoxia. Embo J. 2003;22 (16):4082-4090. doi:10.1093/emboj/cdg392

5. Huang LE, Gu J, Schau M, Bunn HF. Regulation of hypoxia-inducible factor 1alpha is mediated by an O2-dependent degradation domain via the ubiquitin-proteasome pathway. Proc Natl Acad Sci USA. 1998;95(14):7987-7992.

6. Maxwell PH, Wiesener MS, Chang GW, et al. The tumour suppressor protein VHL targets hypoxia-inducible factors for oxygen-dependent proteolysis. Nature. 1999;399(6733):271-275. doi: 10.1038/20459

7. Appelhoff RJ, Tian Y-M, Raval RR, et al. Differential function of the prolyl hydroxylases PHD1, PHD2, and PHD3 in the regulation of hypoxia-inducible factor. J Biol Chem. 2004;279(37):38458-38465. doi:10.1074/jbc.M406026200

8. Clifton IJ, McDonough MA, Ehrismann D, Kershaw NJ, Granatino N, Schofield CJ. Structural studies on 2-oxoglutarate oxygenases and related double-stranded beta-helix fold proteins. J Inorg Biochem. 2006;100(4):644-669. doi:10.1016/j.jinorgbio. 2006.01.024

9. Ozer A, Bruick RK. Non-heme dioxygenases: cellular sensors and regulators jelly rolled into one? Nat Chem Biol. 2007;3(3):144-153. doi: $10.1038 /$ nchembio863

10. Vissers MCM, Gunningham SP, Morrison MJ, Dachs GU, Currie MJ. Modulation of hypoxia-inducible factor-1 alpha in cultured primary cells by intracellular ascorbate. Free Radic Biol Med. 2007;42 (6):765-772. doi:10.1016/j.freeradbiomed.2006.11.023

11. Kuiper C, Molenaar IGM, Dachs GU, Currie MJ, Sykes PH, Vissers MCM. Low ascorbate levels are associated with increased hypoxia-inducible factor-1 activity and an aggressive tumor phenotype in endometrial cancer. Cancer Res. 2010;70(14):5749-5758. doi:10.1158/0008-5472.CAN-10-0263

12. Kuiper C, Dachs GU, Munn D, et al. Increased tumor ascorbate is associated with extended disease-free survival and decreased hypoxia-inducible factor-1 activation in human colorectal cancer. Front Oncol. 2014;4:10. doi:10.3389/fonc.2014.00010

13. Jóźwiak P, Ciesielski P, Zaczek A, et al. Expression of hypoxia inducible factor $1 \alpha$ and $2 \alpha$ and its association with vitamin $C$ level in thyroid lesions. J Biomed Sci. 2017;24(1):83. doi:10.1186/s12929017-0388-y 
14. Wohlrab C, Vissers MCM, Phillips E, Morrin H, Robinson BA, Dachs GU. The association between ascorbate and the hypoxia-inducible factors in human renal cell carcinoma requires a functional Von Hippel-Lindau protein. Front Oncol. 2018;8:574. doi:10.3389/fonc.2018.00574

15. Jaakkola P, Mole DR, Tian YM, et al. Targeting of HIF-alpha to the von Hippel-Lindau ubiquitylation complex by O2-regulated prolyl hydroxylation. Science. 2001;292(5516):468-472. doi:10.1126/ science. 1059796

16. Flashman E, Davies SL, Yeoh KK, Schofield CJ. Investigating the dependence of the hypoxia-inducible factor hydroxylases (factor inhibiting HIF and prolyl hydroxylase domain 2) on ascorbate and other reducing agents. Biochem J. 2010;427(1):135-142. doi:10.1042/BJ20091609

17. Levine M, Wang Y, Padayatty SJ, Morrow J. A new recommended dietary allowance of vitamin $\mathrm{C}$ for healthy young women. Proc Natl Acad Sci USA. 2001;98(17):9842-9846. doi:10.1073/pnas.171318198

18. Kuiper C, Dachs GU, Currie MJ, Vissers MCM. Intracellular ascorbate enhances hypoxia-inducible factor (HIF)-hydroxylase activity and preferentially suppresses the HIF-1 transcriptional response. Free Radic Biol Med. 2014;69:308-317. doi:10.1016/j.freeradbiomed.2014.01.033

19. May JM. The SLC23 family of ascorbate transporters: ensuring that you get and keep your daily dose of vitamin C. Br J Pharmacol. 2011;164(7):1793-1801. doi:10.1111/j.1476-5381.2011.01350.x

20. Srinivasan R, Ricketts CJ, Sourbier C, Linehan WM. New strategies in renal cell carcinoma: targeting the genetic and metabolic basis of disease. Clin Cancer Res. 2015;21(1):10-17. doi:10.1158/1078-0432. CCR-13-2993

21. Raval RR, Lau KW, Tran MGB, et al. Contrasting properties of hypoxia-inducible factor 1 (HIF-1) and HIF-2 in von Hippel-Lindauassociated renal cell carcinoma. Mol Cell Biol. 2005;25 (13):5675-5686. doi:10.1128/MCB.25.13.5675-5686.2005

22. Whaley JM, Naglich J, Gelbert L, et al. Germ-line mutations in the von Hippel-Lindau tumor-suppressor gene are similar to somatic von Hippel-Lindau aberrations in sporadic renal cell carcinoma. $\mathrm{Am}$ J Hum Genet. 1994;55(6):1092-1102.

23. Arias-Gonzalez L, Moreno-Gimeno I, Del Campo AR, et al. ERK5/ BMK1 is a novel target of the tumor suppressor VHL: implication in clear cell renal carcinoma. Neoplasia. 2013;15(6):649-659.

24. Timenetsky J, Santos LM, Buzinhani M, Mettifogo E. Detection of multiple mycoplasma infection in cell cultures by PCR. Braz J Med Biol Res. 2006;39(7):907-914.

25. Lois C, Hong EJ, Pease S, Brown EJ, Baltimore D. Germline transmission and tissue-specific expression of transgenes delivered by lentiviral vectors. Science. 2002;295(5556):868-872. doi:10.1126/ science. 1067081

26. Naldini L, Blömer U, Gallay P, et al. In vivo gene delivery and stable transduction of nondividing cells by a lentiviral vector. Science. 1996;272(5259):263-267.

27. Shinojima T, Oya M, Takayanagi A, Mizuno R, Shimizu N, Murai M. Renal cancer cells lacking hypoxia inducible factor (HIF)-1alpha expression maintain vascular endothelial growth factor expression through HIF-2alpha. Carcinogenesis. 2007;28(3):529-536. doi:10.1093/carcin/ bg1143

28. Kong X, Alvarez-Castelao B, Lin Z, Castaño JG, Caro J. Constitutive/hypoxic degradation of HIF-alpha proteins by the proteasome is independent of von Hippel Lindau protein ubiquitylation and the transactivation activity of the protein. J Biol Chem. 2007;282 (21):15498-15505. doi:10.1074/jbc.M700704200

29. Koh MY, Powis G. Passing the baton: the HIF switch. Trends Biochem Sci. 2012;37(9):364-372. doi:10.1016/j.tibs.2012.06.004

30. Biswas S, Troy H, Leek R, et al. Effects of HIF-1alpha and HIF2-alpha on growth and metabolism of clear-cell renal cell carcinoma 786-0 xenografts. $J$ Oncol. 2010;2010:757908. doi:10.1155/ 2010/757908
31. Michels AJ, Hagen TM, Frei B. Human genetic variation influences vitamin $\mathrm{C}$ homeostasis by altering vitamin $\mathrm{C}$ transport and antioxidant enzyme function. Annu Rev Nutr. 2013;33(1):45-70. doi:10.1146/annurev-nutr-071812-161246

32. Du J, Cullen JJ, Buettner GR. Ascorbic acid: chemistry, biology and the treatment of cancer. Biochim Biophys Acta. 2012;1826 (2):443-457. doi:10.1016/j.bbcan.2012.06.003

33. Clément MV, Ramalingam J, Long LH, Halliwell B. The in vitro cytotoxicity of ascorbate depends on the culture medium used to perform the assay and involves hydrogen peroxide. Antioxid Redox Signal. 2001;3(1):157-163. doi:10.1089/152308601750100687

34. Bergsten P, Amitai G, Kehrl J, Dhariwal KR, Klein HG, Levine M. Millimolar concentrations of ascorbic acid in purified human mononuclear leukocytes. Depletion and reaccumulation. $J$ Biol Chem. 1990;265(5):2584-2587.

35. Butler JD, Bergsten P, Welch RW, Levine M. Ascorbic acid accumulation in human skin fibroblasts. Am J Clin Nutr. 1991;54 (6Suppl):1144S-1146S. doi:10.1093/ajen/54.6.1144s

36. Liang W-J, Johnson D, Ma L-S, Jarvis SM, Wei-Jun L. Regulation of the human vitamin $\mathrm{C}$ transporters expressed in COS-1 cells by protein kinase C. Am J Physiol Cell Physiol. 2002;283(6):C16961704. doi:10.1152/ajpcell.00461.2001

37. Schleicher RL, Carroll MD, Ford ES, Lacher DA. Serum vitamin $\mathrm{C}$ and the prevalence of vitamin $\mathrm{C}$ deficiency in the United States: 2003-2004 National Health and Nutrition Examination Survey (NHANES). Am J Clin Nutr. 2009;90(5):1252-1263. doi:10.3945/ ajen.2008.27016

38. Kuiper C, Vissers MCM, Hicks KO. Pharmacokinetic modeling of ascorbate diffusion through normal and tumor tissue. Free Radic Biol Med. 2014;77:340-352. doi:10.1016/j. freeradbiomed.2014.09.023

39. Campbell EJ, Vissers MC, Dachs GU. Ascorbate availability affects tumor implantation-take rate and increases tumor rejection in Gulo-/-mice. Hypoxia (Auckl). 2016;4:41-52. doi:10.2147/HP. $\mathrm{S} 103088$

40. Tian Y-M, Yeoh KK, Lee MK, et al. Differential sensitivity of hypoxia inducible factor hydroxylation sites to hypoxia and hydroxylase inhibitors. $J$ Biol Chem. 2011;286(15):13041-13051. doi:10.1074/jbc.M110.211110

41. Singleton RS, Trudgian DC, Fischer R, Kessler BM, Ratcliffe PJ, Cockman ME. Quantitative mass spectrometry reveals dynamics of factor-inhibiting hypoxia-inducible factor-catalyzed hydroxylation. $J$ Biol Chem. 2011;286(39):33784-33794. doi:10.1074/jbc. M111.262808

42. Islam MS, Leissing TM, Chowdhury R, Hopkinson RJ, Schofield CJ. 2-oxoglutarate-dependent oxygenases. Annu Rev Biochem. 2018;87:585-620. doi:10.1146/annurev-biochem $-061516-044724$

43. Rose NR, McDonough MA, King ONF, Kawamura A, Schofield CJ. Inhibition of 2-oxoglutarate dependent oxygenases. Chem Soc Rev. 2011;40(8):4364-4397. doi:10.1039/c0cs00203h

44. Kuiper C, Vissers MCM. Ascorbate as a co-factor for fe- and 2-oxoglutarate dependent dioxygenases: physiological activity in tumor growth and progression. Front Oncol. 2014;4:359. doi:10.3389/fonc.2014.00359

45. Chan DA, Sutphin PD, Yen S-E, Giaccia AJ. Coordinate regulation of the oxygen-dependent degradation domains of hypoxia-inducible

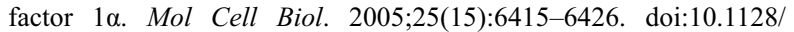
MCB.25.15.6415-6426.2005

46. Hu C-J, Wang L-Y, Chodosh LA, Keith B, Simon MC. Differential roles of hypoxia-inducible factor 1alpha (HIF-1alpha) and HIF-2alpha in hypoxic gene regulation. Mol Cell Biol. 2003;23(24):9361-9374.

47. Gordan JD, Bertout JA, Hu C-J, Diehl JA, Simon MC. HIF-2alpha promotes hypoxic cell proliferation by enhancing c-myc transcriptional activity. Cancer Cell. 2007;11(4):335-347. doi:10.1016/j. ccr.2007.02.006 
48. Khan MN, Bhattacharyya T, Andrikopoulos $\mathrm{P}$, et al. Factor inhibiting HIF (FIH-1) promotes renal cancer cell survival by protecting cells from HIF-1 $\alpha$-mediated apoptosis. $B r \quad J$ Cancer. 2011;104 (7):1151-1159. doi:10.1038/bjc.2011.73

49. Suzuki N, Vojnovic N, Lee KL, Yang H, Gradin K, Poellinger L. HIF-dependent and reversible nucleosome disassembly in hypoxia-inducible gene promoters. Exp Cell Res. 2018;366 (2):181-191. doi:10.1016/j.yexcr.2018.03.020

50. Smythies JA, Sun M, Masson N, et al. Inherent DNA-binding specificities of the HIF- $1 \alpha$ and HIF- $2 \alpha$ transcription factors in chromatin. EMBO Rep. 2019;20(1):pii: e46401. doi:10.15252/ embr.201846401

51. Dayan F, Bilton RL, Laferrière J, et al. Activation of HIF-1alpha in exponentially growing cells via hypoxic stimulation is independent of the Akt/mTOR pathway. $J$ Cell Physiol. 2009;218(1):167-174. doi:10.1002/jcp. 21584

52. Wenger RH, Kurtcuoglu V, Scholz CC, Marti HH, Hoogewijs D. Frequently asked questions in hypoxia research. Hypoxia (Auckl). 2015;3:35-43. doi:10.2147/HP.S92198
53. Manisterski M, Golan M, Amir S, Weisman Y, Mabjeesh NJ. Hypoxia induces PTHrP gene transcription in human cancer cells through the HIF-2 $\alpha$. Cell Cycle. 2010;9(18):3723-3729.

54. Dachs GU, Steele AJ, Coralli C, et al. Anti-vascular agent Combretastatin A-4-P modulates hypoxia inducible factor-1 and gene expression. BMC Cancer. 2006;6:280.

55. Liu Y, Beyer A, Aebersold R. On the Dependency of Cellular Protein Levels on mRNA Abundance. Cell. 2016;165(3):535-550. doi:10.1016/j.cell.2016.03.014

56. Vogel $\mathrm{C}$ and Marcotte EM. Insights into the regulation of protein abundance from proteomic and transcriptomic analyses. Nat Rev Genet. 2012;13(4):227-232. doi:10.1038/nrg3185

57. Thienpont B, Steinbacher J, Zhao H, et al. Tumour hypoxia causes DNA hypermethylation by reducing TET activity. Nature. 2016;537 (7618):63-68. doi:10.1038/nature19081

58. An J, Rao A, Ko M. TET family dioxygenases and DNA demethylation in stem cells and cancers. Exp Mol Med. 2017;49(4):e323. doi: $10.1038 / \mathrm{emm} .2017 .5$ 


\section{Supplementary material}

Caki-2 20\% O2

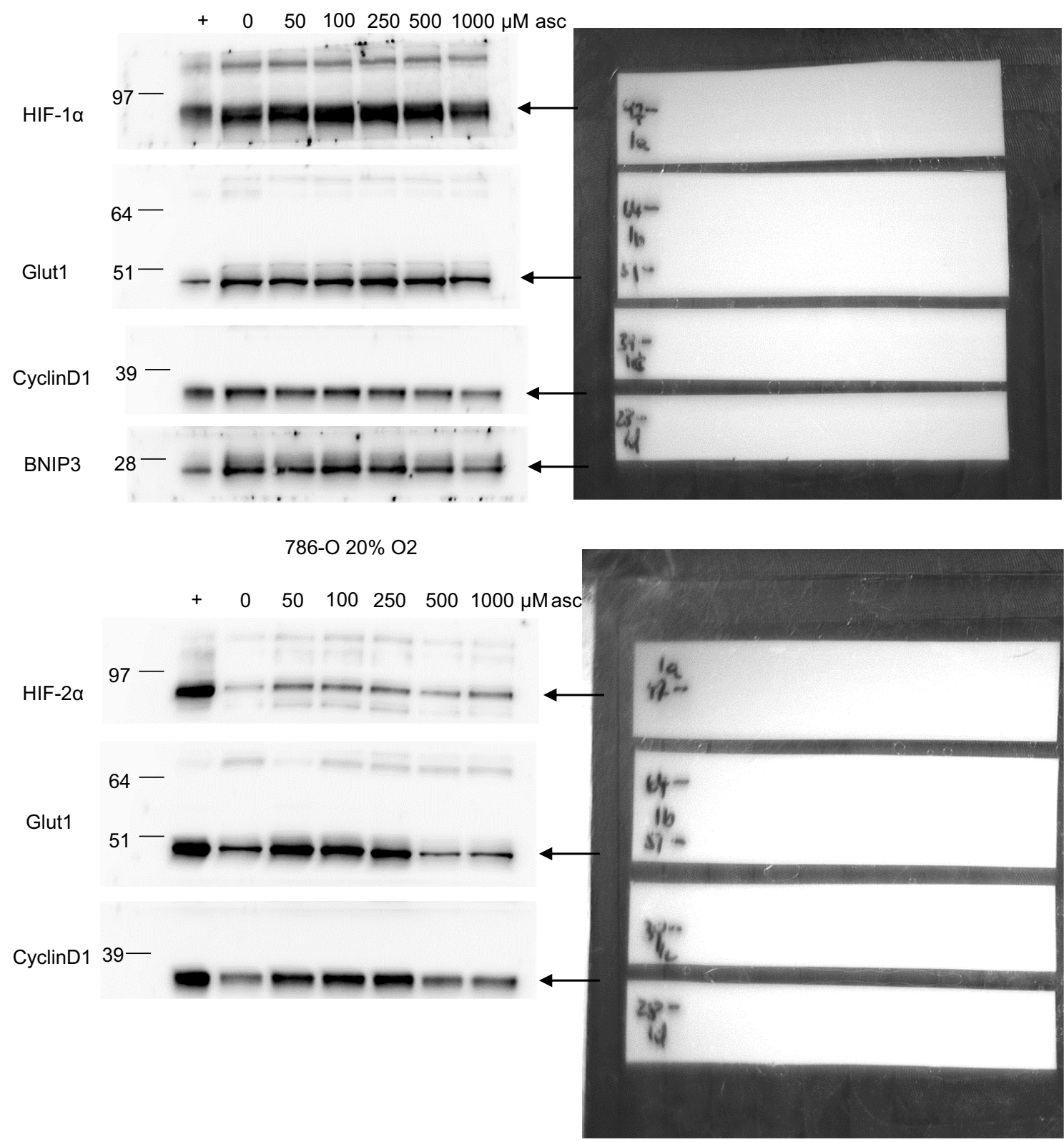

Figure SI Examples of Western blots showing how several HIF pathway proteins were detected on a single gel by cutting membranes into strips. Original chemiluminescent detection of proteins is shown on the left and the associated membrane strips on the right. Molecular size markers are indicated.

\section{Publish your work in this journal}

Hypoxia is an international, peer-reviewed, open access journal that aims to improve understanding of the biological response to hypoxia. The journal will publish original research articles, reviews, methodological advances, clinical studies, and expert opinions that identify developments in the regulation of the physiological and

Submit your manuscript here: https:/www.dovepress.com/hypoxia-journal pathological responses to hypoxia and in the therapeutic targeting of hypoxia-responsive pathways. The manuscript management system is completely online and includes a very quick and fair peer-review system, which is all easy to use. Visit http://www.dovepress.com/ testimonials.php to read real quotes from published authors. 